\title{
Oral Health Status of Institutionalized Orphans and Non-Orphans Aged 6-12 Years in a Central Indian City: A Comparative Study
}

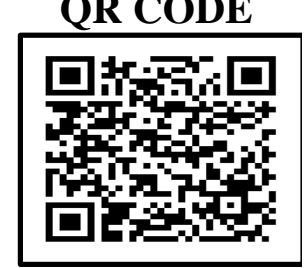

\section{KARISHMA A ${ }^{1}$, ANUJ NAIR ${ }^{2}$, ANJALI D³, INDRAJEET SINGH ${ }^{* 4}$}

INTRODUCTION: Oral Health, like general health, is a basic fundamental right for all, and even more so for the underprivileged.

AIM: To evaluate the oral health status of Institutionalized orphans aged 6-12 years and non-orphans in Indore, Madhya Pradesh

MATERIALS AND METHOD: The present descriptive cross-sectional study was conducted among various registered orphanages in Indore,

Madhya Pradesh. Oral Examination was done by two standardized examiners (ADA type III examination) and data was entered using a pre-tested and pre-validated proforma. Data was transferred into MS excel and after application of descriptive statistics, the independent samples t-test and multiple logistic regression were applied ( $\mathrm{p}$ value significant at $\leq 0.5$ ).

RESULTS: Of the total 263 study subjects, there were 132(50.2\%) orphans and 131(49.8\%) school children aged 6-12 years. Among orphans, males (62.9\%) formed the majority; use of toothbrush with toothpaste was observed among $69.7 \%$ of orphans, while $6.1 \%$ did not use any oral hygiene aid. The most common observed hard lesion was dental caries $(31.8 \%)$ as compared to $20.6 \%$ in school children and its presence revealed a significant association $(\mathrm{p}=0.02)$.

CONCLUSION: It is recommended that a special emphasis should be made to promote oral health among the children residing in orphanages.

KEYWORDS: Orphans, Dental Caries, Toothbrushing

\section{INTRODUCTION}

Oral health, a basic human right for people is necessary for having a healthy and a good quality of life. ${ }^{1}$ Even in this ever progressing world, due to social and financial factors, oral care remains more focused on treatment than on prevention. ${ }^{2}$ It is said that oral health is an integral part of general health; and its neglect results in negative/undesirable health and social consequences. ${ }^{3}$

In many low-income/developing countries, dental caries still is a major problem with limited access to oral health and teeth are often left untreated or are extracted because of pain. ${ }^{4}$ Among such populations, orphans are at a high risk of having and/or developing dental diseases. Reasons for residing in an orphanage can vary from parental neglect, absence, substance abuse to abandonment (undesired child) and are at risk for developing abnormal psychosocial development. ${ }^{5}$

Various authors have documented the fact that oral health issues are more prevalent among deprived groups including orphans of both developing and developed countries. ${ }^{6}$ In addition, children living in an orphanage are at a risk to develop nutritional deficiency as a result of which malnutrition, anemia, and delays in growth are observed among them.
Due to the neglected oral health among orphans, the present study aimed to evaluate the oral health status of Institutionalized orphans aged 6-12 years and nonorphans in Indore, Madhya Pradesh and the application of this data for the betterment of oral care among orphans, if required.

\section{MATERIALS AND METHOD}

The present descriptive cross-sectional study was conducted among various registered orphanages in Indore, Madhya Pradesh from $25^{\text {th }}$ September, 2018 to $24^{\text {th }}$ September, 2019 and after taking due approvals/permissions (including ethical approval) from the concerned authorities.

Data was collected using a proforma and entered by two standardized operators as per the directions of two investigators [also standardized before the study; Inter examiner variability (k): .071] who conducted an ADA type III examination under natural/ artificial light (based on availability).

All respondents and their caretakers were assured of the confidentiality of their data and data was coded and only available with the primary investigator. Data was 
transferred into MS excel and after application of descriptive statistics, was transferred to SPPS version 16.o and the independent samples t-test and multiple logistic regression was applied keeping the $\mathrm{p}$ value significant at $\leq 0.5$

\section{RESULTS}

It was observed that of the total 263 study subjects, there were $132(50.2 \%)$ orphans and $131(49.8 \%)$ school children aged 6-12 years. Among orphans, males $(62.9 \%)$ formed the majority and matched male school children (59.5\%) were recruited for the present study (table 1).

\begin{tabular}{c|c|c}
\multicolumn{2}{c}{ OPRHANS } & $\begin{array}{c}\text { SCHOOL } \\
\text { CHILDREN }\end{array}$ \\
\hline Males & $83(62.9 \%)$ & $78(59.5 \%)$ \\
Females & $49(37.1)$ & $53(40.5 \%)$ \\
Total & $132(50.2 \%)$ & $131(49.8 \%)$
\end{tabular}

Table 1. Distribution of Orphans and School Children

The oral hygiene aids used by the children is shown in table 2. Use of toothbrush with toothpaste as observed among $69.7 \%$ of orphans, while $6.1 \%$ did not use any oral hygiene aid. Among school children, a majority of them $(97.7 \%, \mathrm{p}=0.03)$ used toothbrush with toothpaste and only $2.3 \%$ reported using a finger with a toothbrush.

\begin{tabular}{|c|c|c|c|}
\hline $\begin{array}{c}\text { Oral Hygiene } \\
\text { Aid used }\end{array}$ & Orphans & $\begin{array}{l}\text { School } \\
\text { Children }\end{array}$ & $\begin{array}{l}\text { p-value } \\
\text { (derived } \\
\text { from } t)\end{array}$ \\
\hline None & $8(6.1 \%)$ & o $(0 \%)$ & NS \\
\hline $\begin{array}{c}\text { Chew } \\
\text { Stick/Neem } \\
\text { stick/Charcoal } \\
\end{array}$ & $16(12.1 \%)$ & o(o\%) & NS \\
\hline $\begin{array}{l}\text { Toothpaste } \\
\text { and Finger }\end{array}$ & $16(12.1 \%)$ & $3(2.3 \%)$ & NS \\
\hline $\begin{array}{l}\text { Toothpaste } \\
\text { with } \\
\text { toothbrush }\end{array}$ & $\begin{array}{c}92 \\
(69.7 \%)\end{array}$ & $128(97 \cdot 7 \%)$ & 0.03 \\
\hline Total & 132 & 131 & oo \\
\hline
\end{tabular}

Table 2. Use of Oral Hygiene Aids by Orphans and Children (NS: Non-Significant)

Table 3 describes the presence of hard and soft lesions among both groups. In orphans, the most common observed hard lesion was dental caries (31.8\%) as compared to $20.6 \%$ in school children; the difference was found to be significant $(\mathrm{p}=0.05)$. Among schoolchildren, "other" hard lesions were majorly found $(37.5 \%)$. It was observed that $48.5 \%$ of orphans and $77.3 \%$ of school children did not have any soft tissue lesion(s) and among ones observed, both groups showed a maximum number of coated tongue(orphans: 19.6\%, School children: $10.7 \%$ ) and statistical analysis of soft tissue revealed no significant association.

The multiple linear regression model to analyze the difference between hard and soft tissue lesions in relation to both groups revealed a significant association between hard tissue lesions $(\mathrm{p}=\mathbf{0 . 0 2}$, table 4).

\section{DICUSSSION}

As per findings of the present study, it was reported that both use of improper oral hygiene aids as well as presence of hard and soft tissue lesions were more prevalent among orphans as compared to non-orphans and this can be attributed to the individualized care provided by the parents of non-orphans, as compared to orphans, who are under the guidance of a caretaker are usually socially and economically deprived. ${ }^{7}$

More orphan males (62.9\%) were observed among the orphanges surveyed in the present study, and this is in agreement to the findings of Soni A et al. (65.37\% males $)^{8}$ and Shah AF et al. (72.2.\% males). ${ }^{9}$ However, in disagreement, to our findings, Bennadi $\mathrm{D}$ et al. ${ }^{6}$ documented a higher percentage of institutionalized female orphans (83\%) and the variations in the above findings can be attributed to the time at which the studies were conducted, as well as due to geographic locations of the orphanages.

The use a toothbrush and toothpaste in the present study was reported as $69.7 \%$ among orphans and $97.7 \%$ among non-orphans. This is lower as per the findings of Hans R et al. $(82 \%)^{10}$ and Kumar APP et al.," ${ }^{11}$ who reported $90.8 \%$ brushing habit using toothbrush and toothpaste among orphan children. Among school children $97.7 \%$ reported brushing habit using toothbrush and toothpaste and is in agreement to Mishra A et al. who reported $97.1 \%$ of their study population (school going children) using toothpaste as the medium for cleaning teeth, while the rest $2.9 \%$ used powder/charcoal and its products to clean the teeth. ${ }^{12}$

A positive finding of the present study was that dental caries was reported only in $31.8 \%$ of orphans and $20.6 \%$ 


\begin{tabular}{|c|c|c|c|}
\hline HARD TISSUE FINDINGS & ORPHANS & SCHOOL CHILDREN & $\begin{array}{l}\text { P-VALUE (DERIVED } \\
\text { FROM T) } \\
\end{array}$ \\
\hline \multicolumn{4}{|c|}{ HARD TISSUE FINDINGS } \\
\hline Dental Caries & $42(31.8 \%)$ & $27(20.6 \%)$ & 0.05 \\
\hline Fluorosis & $16(12.1 \%)$ & $18(13.7 \%)$ & \multirow{5}{*}{ NS } \\
\hline Tooth Fracture & $39(29 \cdot 5 \%)$ & $3(2.3 \%)$ & \\
\hline Others & $12(9.1 \%)$ & $34(25.9 \%)$ & \\
\hline \multirow[t]{2}{*}{ None } & $23(17.5 \%)$ & $49(37.5 \%)$ & \\
\hline & $132(100 \%)$ & $131(100 \%)$ & \\
\hline \multicolumn{4}{|c|}{ SOFT TISSUE FINDINGS } \\
\hline Apthous Ulcer & $12(9.1 \%)$ & $07(5.3 \%)$ & \multirow{7}{*}{ NS } \\
\hline Coated Tongue & $26(19.6 \%)$ & $14(10.7 \%)$ & \\
\hline Fissured Tongue & $04(3.0 \%)$ & $\mathrm{Ol}(0.7 \%)$ & \\
\hline Partial Ankyloglossia & $1(0.8 \%)$ & $\mathrm{o}(\mathrm{o} \%)$ & \\
\hline Bifid Tongue & $1(0.8 \%)$ & $1(0.7 \%)$ & \\
\hline Others & $24(18.2 \%)$ & $7(5.3 \%)$ & \\
\hline \multirow[t]{2}{*}{ None } & $64(48.5 \%)$ & $101(77.3 \%)$ & \\
\hline & $132(100 \%)$ & $131(100 \%)$ & oo \\
\hline
\end{tabular}

Table 3. Distribution of Hard Tissue Findings in Orphans and School Children

non-orphans. This is in partial agreement to Shah AF et al. (25.2\%; orphans aged 7-11 years). 9 These findings are in agreement to those found among Mexican schoolchildren (49.4\%; school children aged 6-13 years). ${ }^{13}$ In disagreement, a higher caries was reported by Shingare P et al. ${ }^{14}$ (88.61\% among school children aged 7-10 years and $73 \%$ among school children aged 1114 years) and among Orphans, $80 \%$ of caries prevalence was reported by Bennadi D et al. ${ }^{6}$ Such variations can be attributed to individual beliefs (especially parents ) and the self-motivation regarding oral hygiene among caretakers of orphanages.

Fracture of the tooth was reported to be $29.5 \%$ as compared to $2.3 \%$ among non-orphans and this high percentage among orphans is similar to the findings of Bennadi D et al. (22\%) and is a resultant of higher oral neglect and monetary constraints in orphanages. ${ }^{6}$ A bivariate logistic regression revealed a significant observation between hard tissue lesions among orphans and non-orphans $\left(\mathrm{p}=\mathrm{O}^{\circ} \mathrm{O2}^{*}\right)$.

\begin{tabular}{|c|c|c|}
\hline & $\begin{array}{l}\text { Hard Tissue } \\
\text { Findings }\end{array}$ & $\begin{array}{l}\text { Soft Tissue } \\
\text { Findings }\end{array}$ \\
\hline $\begin{array}{c}\text { Orphans * } \\
\text { School } \\
\text { children }\end{array}$ & 0.02 * & NS \\
\hline
\end{tabular}

Table 4. Association Between Hard Tissue and Soft Tissue Findings Between Both Groups

\section{CONCLUSION}

Based on the findings of the present study, it is recommended that a special emphasis should be made to promote oral health among orphanages and affordable/free treatment be provided to the children so that they can also restore their smile for life.

\section{REFERENCES}

1. Petersen PE. Strengthening of oral health systems: oral health through primary health care. Med Princ Pract 2014; 23(1):3-9. https://doi.org/10.1159/000356937 2. Lulëjeta F, Venera B, Jeta K, Tetore O. Oral Health Status Among 12-Year-Old Schoolchildren in Kosovo. Pesqui. Bras. Odontopediatria Clín Integr. 2020;20:eo039. https://doi.org/10.1590/pboci.2020.082 3. Tomar SP, Kasar PK, Tiwari R. Study of oral hygienic practices and oral health status among school children in Jabalpur, Madhya Pradesh: a cross-sectional study. Int J Community Med Public Health. 2016;3:403-7. http://doi.org/10.18203/2394-6040.ijcmph20160093 4. Petersen PE. The World Oral Health Report 2003: continuous improvement of oral health in the 21st century - the approach of the WHO Global Oral Health Programme. Community Dent Oral Epidemiol 2003; 31(1):3-24. https://doi.org/1.01046/j.2003.com122.x

5. Sharma A, Gaur A, Pareek S, Raja V, Sanadhya S, Sharma AV. Oral health status and treatment needs among orphanage children of Jaipur City. Sch J Appl Med Sci. 2014;2:1776-80

6. Bennadi D, Shabanam S, Abdul NN, Jacob A, Malini $\mathrm{K}$, Bharateesh JV. Oral health status of orphanage 
children, Tumkur: A survey report. Int J Community Dent 2018;6:27-9. https://doi.org/10.4103/ijcd.ijcd_3_18 7. Cluver L, Gardner F, Operario D. Psychological distress amongst AIDS-orphaned children in urban South Africa. J Child Psychol Psychiatry 2007;48:75563.

8. Soni A, Sharma H, Motghare V, Verma S. Assessment of oral health status in orphanage inmates of northeastern part of Rajasthan: A descriptive cross-sectional study. J Indian Assoc Public Health Dent. 2020;18:13942. https://doi.org/10.4103/jiaphd.jiaphd_104_19 9. Shah AF, Tangade P, Ravishankar TL, Tirth A, Pal S, Batra M. Dental Caries Status of Institutionalized Orphan Children from Jammu and Kashmir, India. Int J Clin Pediatr Dent. 2016;9(4):364-371. https://doi.org/10.5005/jp-journals-10005-1392

10. Hans R, Thomas S, Dagli R, Bhateja GA, Sharma A, Singh A. Oral Health Knowledge, Attitude and Practices of Children and Adolescents of Orphanages in Jodhpur City Rajasthan, India. J Clin Diagn Res. 2014;
8(10):

$$
\mathrm{ZC22}-\mathrm{ZC} 25 .
$$

https://doi.org/10.786o/JCDR/2014/9026.4948

11. Kumar APP, Shankar S, Sowmya J, Priyaa CV. Oral health Knowledge Attitude Practice of School students of KSR Matriculation School, Thiruchengode. J Indian Acad Dent Specialists. 2010;1(1):5-11.

12. Mishra A, Pandey RK, Chopra H, Arora V. Oral health awareness in school-going children and its significance to parent's education level. J Indian Soc Pedod Prev Dent. 2018;36:120-4. https://doi.org/10.4103/JISPPD.JISPPD_1172_17

13. Casanova-Rosado AJ, Medina-Solís CE, CasanovaRosado JF, Vallejos-Sánchez AA, Maupomé G, AvilaBurgos L. Dental caries and associated factors in Mexican schoolchildren aged 6-13 years. Acta Odontol Scand. 2005;63(4):245-51.

14. Shingare P, Jogani V, Sevekar S, Patil S, Jha M. Dental Caries Prevalence among 3- to 14-Year- Old School Children, Uran, Raigad District, Maharashtra. J Contemp Dent. 2012;2(2):11-4. 